\title{
Plasma prolactin levels in sows during pregnancy, parturition and early lactation
}

\author{
Luiza Dusza and Halina Krzymowska
}

Institute of Animal Physiology and Biochemistry, Academy of Agriculture and Technology, 10-718 Olsztyn, Poland

\begin{abstract}
Summary. Mean prolactin concentrations in the blood plasma ranged from 4.4 to $13.0 \mathrm{ng} / \mathrm{ml}$ during pregnancy up to the $2 \mathrm{nd}$ day pre partum. Concentrations increased to $20.3 \mathrm{ng} / \mathrm{ml} 2$ days before and $103.4 \mathrm{ng} / \mathrm{ml}$ at 1 day before the start of farrowing. During farrowing values ranged from 124.2 to $147.3 \mathrm{ng} / \mathrm{ml}$. On the 5th day of lactation the prolactin levels had fallen to $43 \cdot 1 \mathrm{ng} / \mathrm{ml}$.
\end{abstract}

\section{Introduction}

Prolactin concentrations in sows during pregnancy have not so far been investigated except for the fragmentary studies of Threlfall, Dale \& Martin (1974) who determined plasma prolactin values in sows at mid-gestation (60 days) and on the 112 th day of gestation. Prolactin values were measured during parturition and subsequent lactation by Van Landeghem \& Van de Wiel (1978) and during lactation by Bevers, Willemse \& Kruip (1978) and Mulloy \& Malven (1979). We have examined peripheral plasma levels of prolactin in cyclic sows (Dusza \& Krzymowska, 1979) and in the present study this work was extended to pregnant, parturient and lactating sows.

\section{Materials and Methods}

Sows of the Polish Large White breed were kept in the conditions of an industrial pig farm. The groups of sows were as follows: Group I-10 sows in early pregnancy (1-30 days); Group II -5 sows in mid-pregnancy (60-69 days); Group III-11 sows in late pregnancy, at parturition and during early lactation (from 12 days pre partum, during farrowing and up to 5 days post partum). Blood samples were withdrawn from a venous cannula. The cannula was inserted through the vena cephalica humeri into the external jugular vein and exteriorized by passage under the skin to the back. The blood was collected daily at 11:00 h during pregnancy until the start of farrowing, and then at $1 \mathrm{~h}$ intervals during parturition, and daily at 07:00, $11: 00,15: 00$ and 19:00 $\mathrm{h}$ in lactating sows. The heparinized blood samples were centrifuged and plasma was stored at $-20^{\circ} \mathrm{C}$ until assay.

Prolactin assay. Prolactin concentration was estimated by the double-antibody radioimmunoassay method of Schams \& Karg (1969) as modified by Dusza \& Krzymowska (1979). In the present study the porcine prolactin preparation KK-2 (with biological potency of about $30 \mathrm{i} . u$. $/ \mathrm{mg}$ ) was iodinated enzymically by the method of Frantz \& Turkington (1972) with slight modifications. Iodination was carried out at room temperature. Porcine prolactin ( $5 \mu \mathrm{g}$ in $5 \mu \mathrm{l}$ distilled water), $10 \mu \mathrm{l} 0.04 \mathrm{M}$-sodium barbital buffer $\mathrm{pH} 7 \cdot 0,1 \mathrm{mCi}{ }^{125} \mathrm{I}$ (Radiochemical Centre, Amersham, England), lactoperoxidase (Calbiochem, $10 \mu \mathrm{g}$ in $20 \mu \mathrm{l} 0.04 \mathrm{M}$ - 
sodium barbital buffer $\mathrm{pH} 7.0)$ and $\mathrm{H}_{2} \mathrm{O}_{2}(200 \mathrm{ng}$ in $20 \mu$ distilled water) were added in a glass tube $(10 \times 40 \mathrm{~mm})$. After $3.5 \mathrm{~min}$ a second aliquot of $\mathrm{H}_{2} \mathrm{O}_{2}(200 \mathrm{ng})$ was added to the reaction mixture and the reaction was allowed to continue for a further $3.5 \mathrm{~min}$. After adding $200 \mu \mathrm{l}$ cold $\left(5^{\circ} \mathrm{C}\right)$ buffer, the mixture was purified on Sephadex G-50 Super-fine $(1 \times 20 \mathrm{~cm})$. Fractions of ${ }^{125}$ I-labelled prolactin recovered with gel filtration were further purified by gradient chromatography on a $1 \times 20 \mathrm{~cm}$ column of DEAE-Sephadex A-50 using an elution gradient of 0.005$0.5 \mathrm{M}$-potassium phosphate buffer, $\mathrm{pH} \mathrm{7.4}$. Plasma samples were assayed in duplicate at volumes of 10,20 or $50 \mu \mathrm{l}$. The sensitivity of this assay was $0.15 \mathrm{ng}$ prolactin. The intra- and inter-assay variations were 3.2 and $<10 \%$, respectively. The mean \pm s.d. recovery after addition of various amounts of prolactin to the plasma was $110 \cdot 94 \pm 7 \cdot 2 \%(n=30)$.

\section{Results and Discussion}

On the day of mating the mean ( \pm s.e.m.) plasma prolactin concentration was $15.9 \pm 5.5 \mathrm{ng} / \mathrm{ml}$ and thereafter ranged between $4.7 \pm 1.9 \mathrm{ng} / \mathrm{ml}$ and $10.7 \pm 0.8 \mathrm{ng} / \mathrm{ml}$ (Text-fig. 1). At 12-3 days pre partum mean prolactin levels ranged from 7.4 to $13.9 \mathrm{ng} / \mathrm{ml}$ (Text-fig. 2). The peripheral plasma level of prolactin in sows during pregnancy in this study was similar to the basal values in cyclic sows (Dusza \& Krzymowska, 1979). Threlfall, Dale \& Martin (1974) did not find any differences in the prolactin concentrations in sows at mid-gestation and on the 112th day of gestation, but the serum prolactin values reported for pregnant sows were much higher (140.7 and $148.3 \mathrm{ng} / \mathrm{ml}$ ) than those found in the present study. This could be a result of differences in sampling technique (Threlfall et al. slaughtered animals by using firearms of a small and large calibre and collected the blood samples from incised jugular veins) and/or differences in the purified prolactin preparation and in the anti-serum to prolactin.

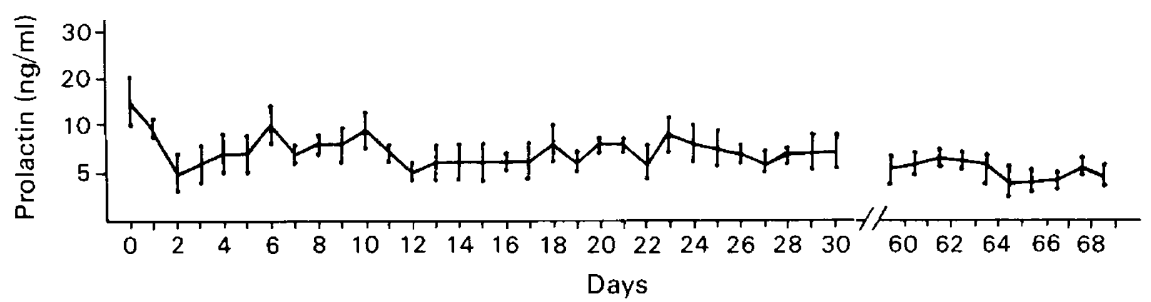

Text-fig. 1. Mean \pm s.e.m. prolactin concentrations in the plasma of 10 sows during early pregnancy and 5 sows during mid-pregnancy. Day $0=$ day of mating.

On the 2nd day before parturition the prolactin level increased to $20.3 \mathrm{ng} / \mathrm{ml}$ and at 1 day before and during farrowing (Text-fig. 3) the average prolactin level was very high (maximum at start of farrowing, $147.3 \mathrm{ng} / \mathrm{ml}$ ). After farrowing, plasma prolactin level decreased gradually to $43.1 \mathrm{ng} / \mathrm{ml}$ on the 5 th day of lactation. Our findings are in agreement with those of Van Landengham \& Van de Wiel (1978), Bevers et al. (1978) and Mulloy \& Malven (1979) who found lower concentrations of prolactin in the plasma of sows during early lactation (8-30 $\mathrm{ng} / \mathrm{ml}, 27 \pm 5 \mathrm{ng} / \mathrm{ml}$, respectively). These discrepancies are probably the consequence of the different method of investigation used.

This work was supported by the Institute of Pathology and Therapy of Animal, Agriculture Academy, Wroclaw, as part of the Research Project of the Ministry of Higher Education, Science and Technology MR-II-10. 


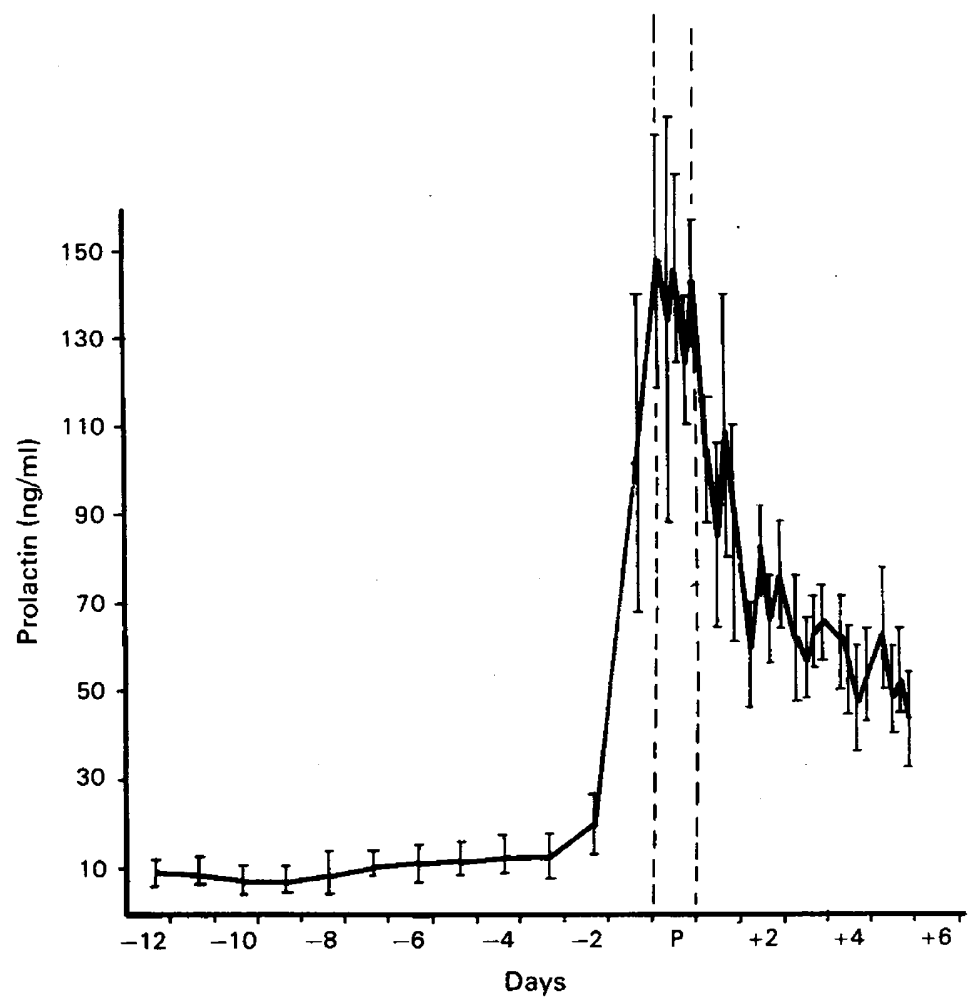

Text-fig. 2. Mean \pm s.e.m. prolactin concentrations in the plasma of 11 sows before ( - ), during and after $(+)$ parturition $(P)$.

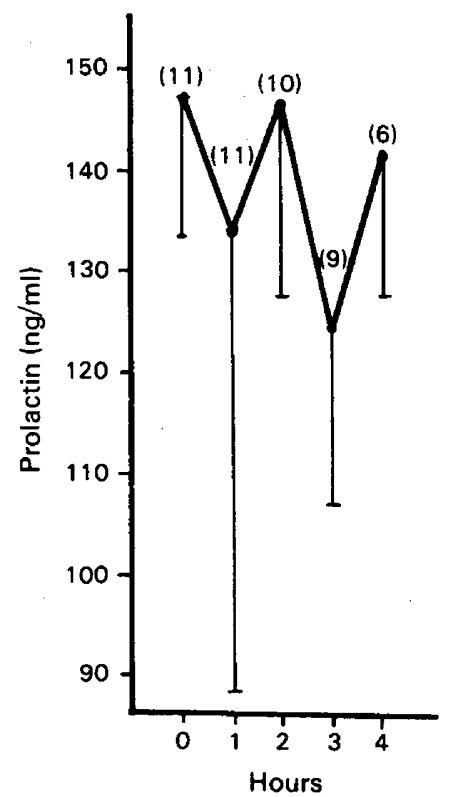

Text-fig. 3. Mean \pm s.e.m. prolactin concentrations in sows (no. in parentheses) during farrowing. Start of farrowing $=0 \mathrm{~h}$. 


\section{References}

Bevers, M.M., Willemse, A.H. \& Kruip, A.M. (1978) Plasma prolactin levels in the sow during lactation and the postweaning period as measured by radioimmunoassay. Biol. Reprod. 19, 628-634.

Dusza, L. \& Krzymowska, H. (1979) Plasma prolactin concentrations during the oestrous cycle of sows. $J$. Reprod. Fert. 57, $511-514$.

Frantz, W.L. \& Turkington, R.W. (1972) Formation of biologically active ${ }^{125}$ I-prolactin by enzymatic radioiodination. Endocrinology 91, 1542-1548.

Mulloy, A.L. \& Malven, P.V. (1979) Relationships between concentrations of porcine prolactin in blood serum and milk of lactating sows. J. Anim. Sci. 48, 876-881.
Schams, D. \& Karg, G.S. (1969) Radioimmunologishe Bestimmung von Prolactin in Blutserum von Rind. Milchwissenschaft 24, 263-265.

Threlfall, W.R., Dale, H.E. \& Martin, Ch.E. (1974) Porcine blood and hypophyseal prolactin values. $\mathrm{Am}$. J. vet. Res. 35, 1491-1493.

Van Landeghem, A.A.J. \& Van de Wiel, D.F.M. (1978) Radioimmunoassay for porcine prolactin plasma levels during lactation, suckling and weaning and after TRH administration. Acta endocr., Copenh. 88, 653-667.

Received 14 April 1980 